\title{
Spatial scale affects bioclimate model projections of climate change impacts on mountain plants
}

\author{
MANDAR R. TRIVEDI*†, PAMELA M. BERRY*, MICHAEL D. MORECROFT $\ddagger$ and \\ TERENCE P. DAWSON§ \\ *Environmental Change Institute, Oxford University Centre for the Environment, South Parks Road, Oxford OX1 3QY, \\ $U K,+$ Centre for Ecology and Hydrology, Lancaster Environment Centre, Library Avenue, Bailrigg, Lancaster LA1 4AP, UK, \\ $\ddagger$ Centre for Ecology and Hydrology, Maclean Building, Crowmarsh Gifford, Wallingford OX10 8BB, UK, §School of Geography, \\ University of Southampton, Highfield, Southampton SO17 1BJ, UK
}

\begin{abstract}
Plant species have responded to recent increases in global temperatures by shifting their geographical ranges poleward and to higher altitudes. Bioclimate models project future range contractions of montane species as suitable climate space shifts uphill. The species-climate relationships underlying such models are calibrated using data at either 'macro' scales (coarse resolution, e.g. $50 \mathrm{~km} \times 50 \mathrm{~km}$, and large spatial extent) or 'local' scales (fine resolution, e.g. $50 \mathrm{~m} \times 50 \mathrm{~m}$, and small spatial extent), but the two approaches have not been compared. This study projected macro (European) and local models for vascular plants at a mountain range in Scotland, UK, under low $\left(+1.7^{\circ} \mathrm{C}\right)$ and high $\left(+3.3^{\circ} \mathrm{C}\right)$ climate change scenarios for the 2080s. Depending on scenario, the local models projected that seven or eight out of 10 focal montane species would lose all suitable climate space at the site. However, the European models projected such a loss for only one species. The cause of this divergence was investigated by cross-scale comparisons of estimated temperatures at montane species' warm range edges. The results indicate that European models overestimated species' thermal tolerances because the input coarse resolution climate data were biased against the cold, high-altitude habitats of montane plants. Although tests at other mountain ranges are required, these results indicate that recent large-scale modelling studies may have overestimated montane species' ability to cope with increasing temperatures, thereby underestimating the potential impacts of climate change. Furthermore, the results suggest that montane species persistence in microclimatic refugia might not be as widespread as previously speculated.
\end{abstract}

Keywords: climate change, downscaling, ecotype, extent, generalized additive models, grain, Grampian Highlands, resolution, Scotland, uncertainty

Received 14 May 2007; revised version received 19 November 2007 and accepted 3 October 2007

\section{Introduction}

The mounting evidence for anthropogenic climate change (IPCC, 2007) and concomitant shifts in species ranges (Parmesan \& Yohe, 2003; Root et al., 2003) has been the catalyst for a growing body of research into the potential impacts of future climate change on the biosphere. A range of approaches has been taken, including laboratory experiments (e.g. Davis et al., 1998), field manipulations (e.g. Harte \& Shaw, 1995) and modelling.

Correspondence: Present address: Mandar R. Trivedi, Global Canopy Programme, John Krebs Field Station, University of Oxford, Wytham OX2 3QJ, UK, tel. +44 1865 724555, fax + 441865 724555, e-mail: mandar.trivedi@gmail.com

(C) 2008 The Authors

Journal compilation (C) 2008 Blackwell Publishing Ltd
The latter can be split into 'mechanistic' models based on ecophysiology (e.g. Prentice et al., 1992) or 'bioclimate envelope' models based on correlations between species distribution and climate (e.g. Bakkenes et al., 2002).

Species distributions correlate with climate at a range of spatial scales. At large scales, species continental ranges are shaped by macroclimate, although historical disturbance factors such as glaciation may constrain potential ranges from being realized (Brown et al., 1996; Svenning \& Skov, 2004; Araújo \& Pearson, 2005). At the smaller scale of an individual mountain range, topography modifies the macroclimate to produce an altitudinal climatic gradient along which species are distributed. Whether considering species ranges in con- 
tinental or altitudinal terms, climate imposes range limits either through direct physiological constraints on survival or reproduction or, indirectly, by mediating biotic interactions such as competition (Gavin \& $\mathrm{Hu}$, 2006). These direct and indirect effects may dominate at opposing range margins, such that the cold (poleward or upper altitudinal) margins are driven by intolerance to a stressful climate while warm margins are delineated by biotic interactions (Brown et al., 1996; Loehle, 1998; Brooker, 2006; Morecroft \& Paterson, 2006).

Much effort has been devoted to clarifying the assumptions, limitations and uncertainty of bioclimate models (Davis et al., 1998; Guisan \& Zimmermann, 2000; Elith et al., 2002; Pearson \& Dawson, 2003; Hampe, 2004; Pearson \& Dawson, 2004; Araújo \& New, 2007; Beaumont et al., 2007; Botkin et al., 2007). Sources of model error can be classed as either 'algorithmic' or 'biotic', referring to whether they concern limitations in the modelling technique or in our understanding of the biological system (Fielding \& Bell, 1997). For example, modelling techniques vary in their ability to predict current ranges (Elith et al., 2006), while different models can give dramatically different predictions of potential future species ranges under climate change (Pearson et al., 2006).

Scale is an important concept in bioclimate modelling (Wiens, 2002), but the effect of scale on the uncertainty of climate change projections has received relatively little consideration (Araújo \& Guisan, 2006). Montane species, here defined as those predominantly found above the treeline, have been modelled at continental (e.g. Berry et al., 2003; Thuiller et al., 2005) and more local scales (e.g. Guisan et al., 1998; Dirnböck et al., 2003). Each scale has its own assumptions, with potential effects on the resulting projections. For example, biotic uncertainty arises with continental scale bioclimate models as they ignore the presence of locally adapted races (ecotypes) across species' ranges and may, therefore, overestimate the ability of local populations to adapt to climate change (Davis \& Shaw, 2001; Hampe, 2004; Harte et al., 2004). Also, data at continental extents tend to have a coarse grain due to the difficulty and expense of sampling species and climate over large areas. The bioclimate model then relates the occurrence of a plant growing on mountainsides to the average climate observed over large grid boxes. Owing to the roughly conical geometry of mountains, the average climate of this box will be weighted towards lower, warmer, altitudes. The microclimate experienced by mountain plants may be very different from this coarse resolution climate (Körner, 1999). Hence, the climate variables entering the model could be biased, resulting in overestimation of the species' thermal tolerance. This may result in an algorithmic error in which the model overestimates the species' current range (Welk \& Bruelheide, 2006), leading to an underestimate of the potential shift in range under climate change.

Local models may, therefore, be more appropriate for projecting climate change impacts on montane species. However, they have the disadvantage of requiring fine resolution climate and species data, which are not easily obtained. Furthermore, nonclimatic factors such as land use may be important drivers of local to regional species distributions (e.g. Dirnböck et al., 2003; Pearson et al., 2004), obscuring the species-climate relationship. The predictions of local models may also be site-specific, with potentially limited relevance for other mountain regions (Randin et al., 2006).

Macro scale bioclimate modelling studies based on species' European distributions have highlighted the vulnerability of montane species to climate change (Berry et al., 2002; Thuiller et al., 2005). But some authors have suggested that species may persist in refuges of suitable local climate, too fine-grained for their macro models to locate. Indeed, conservationists have called for the protection of topographically heterogeneous areas in order to protect such putative climatic refugia (Noss, 2001). However, local models have also demonstrated the sensitivity of individual mountain range floras (e.g. Guisan \& Theurillat, 2000; Dirnböck et al., 2003). Therefore, it is not clear whether such conservation policies would be globally effective.

There is a need to compare the projections of local and macro scale models in order to clarify these issues. In this study, we created local and macro models for species occurring in a single mountain range and quantified the difference in their climate change projections. We tested whether macro models overestimated the climatic tolerance of local populations, leading to underestimation of climate change impacts.

The need of conservation practitioners for local and landscape scale projections of environmental change impacts, combined with the limited availability of high resolution data, have made downscaling an attractive proposition (Araújo et al., 2005; McPherson et al., 2006). While previous attempts have shown promise (Pearson et al., 2004; Araújo et al., 2005), no studies have investigated the effect of the potential bias in macro models of montane species for the downscaling process and the resulting climate change projections. A secondary aim of this study, therefore, was to test whether macro models could be downscaled in a simple fashion to give comparable results to local models.

\section{Methods}

The details of the modelling strategy are described in the following sections, while an overview is given in 
Fig. 1. We created bioclimate models for a set of 10 montane and 10 lowland species at local and European scales. For the local models we used plot-level botanical survey data to predict species distributions on a $50 \mathrm{~m} \times 50 \mathrm{~m}$ grid across a single mountain range in Scotland. The macro models were trained on species' European distributions taken from botanical atlases. These models were used to predict distributions across Great Britain on a $50 \mathrm{~km} \times 50 \mathrm{~km}$ grid. The macro models were also reprojected (downscaled) to a $5 \mathrm{~km} \times 5 \mathrm{~km}$ grid across Great Britain (see Pearson et al., 2002). The predicted species distributions from both the macro and downscaled models were compared with observed British distribution records. We applied climate change scenarios to all three types of model and projected potential future climate space for each species. Species were assumed to be able to disperse to all newly suitable climate space. This may have been unrealistic, but the aim of the study was to assess the influence of the spatial extent of the models, separate from other factors such as dispersal, which have been dealt with by previous authors (e.g. Higgins \& Harte, 2006). The projections of each model (macro, downscaled and local) were compared at the study site.

To aid interpretation of the modelling results, we examined the effect of grain size and spatial extent on the estimation of montane species' thermal tolerances at warm range margins. Species and climate data at local, national and continental scales were used to estimate the observed temperatures at their warm range margins, by finding the estimated warmest grid cells or quadrats in which each species occurred. It was not possible to carry out the same procedure for more widespread lowland species as their warm range margins were not found within the limited local and national extents. However, these species were not expected to be lost from the study site under climate change.

\section{Study area}

The study area extends $30 \mathrm{~km} \times 15 \mathrm{~km}$, across the Breadalbane range of the Grampian Highlands of Scotland, UK (latitude: $56^{\circ} 30^{\prime}$ to $56^{\circ} 34^{\prime}$ and longitude: $4^{\circ} 13^{\prime}$ to $\left.4^{\circ} 19^{\prime}\right)$. The site encompasses three national nature reserves: Ben Lawers, Beinn Heasgarnich and Meall na Samhna. The main axis of the mountain range is aligned in a roughly south-west/north-east direction. Summits vary between 1000 and $1214 \mathrm{~m}$ above sea level (a.s.l.). Unusually for the Scottish Highlands, which are mainly composed of acidic granites, quartzite and schists (Nagy, 2003), the mountains in the Breadalbane range consist of soft Dalradian calcareous mica schists, which give rise to basic, fertile soils supporting a rich arcticalpine flora (Lusby \& Wright, 2001). Below the alpine zone there are glacial drifts of a more acidic nature. The climate is under maritime influence with an average annual maximum temperature of $11.6{ }^{\circ} \mathrm{C}$, minimum temperature of $4.7^{\circ} \mathrm{C}$ and annual rainfall sum of

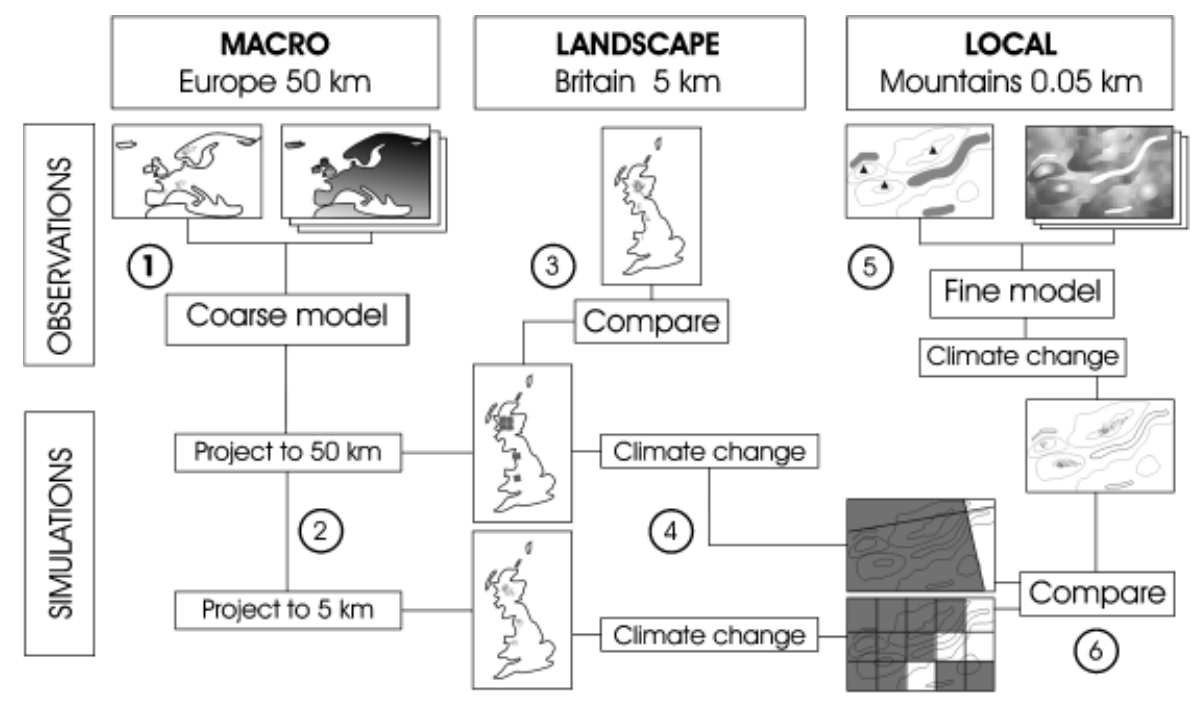

Fig. 1 Strategy for comparing macro and local scale bioclimate models. Step 1 uses atlas distribution maps and bioclimatic variables for Europe to create a macro scale bioclimate model. Step 2 uses this model to predict the current species distribution across Great Britain at both 50 and $5 \mathrm{~km}$ grid resolutions. Step 3 compares the predicted British distribution with the observed species distribution. Step 4 is as step 2, but uses climate change scenarios to give the potential future climate space across Great Britain. Step 5 uses species records from quadrats across three nature reserves (filled triangles) in the Breadalbane mountain range (central Scottish Highlands) and fine resolution bioclimatic variables to create a local bioclimate model, which is then run under climate change scenarios. Step 6 compares the climate change projections of the macro and local models at the extent of the study site. 
$1252 \mathrm{~mm}$ at $130 \mathrm{~m}$ a.s.l. There is a rainfall gradient across the site, increasing by about $2 \mathrm{~cm} \mathrm{yr}^{-1} \mathrm{~km}^{-1}$ westwards, favouring greater peat formation in the west (Poore, 1993). Owing to the cool, moist climate the soils are continually leached, giving rise to podsolic soils even where the underlying bedrocks are nutrient-rich schists. Large areas of podsols underlie much of the Nardus stricta grasslands and heaths of the area. Floristically richer vegetation is found where the soil is enriched through deposits of weathered rock (e.g. at cliff bases) or flushing with water which has run through or over the bedrock (Poore, 1993).

\section{Species distribution data}

Montane species formed the main focus of the study and 10 were chosen for analysis based on the availability of occurrence data at both local and continental scales (Appendix A). Ten other more widespread, lowland species were included as a comparison group. Species distributions across Europe (including north Africa) were taken from atlases (Hultén, 1962; Meusel et al., 1965; Hultén, 1971; Jalas \& Suominen, 1972-1991; Meusel et al., 1978; Hultén \& Fries, 1986; Meusel et al., 1992). The maps were scanned and digitized using ARCGIS (ESRI, Redlands, CA, USA) to give presence/ absence on a $50 \mathrm{~km}$ grid consisting of 7228 cells. Local occurrence data for the study site were taken from field surveys carried out from 2002 to 2004 (Smith et al., 2003; Cornish \& Dayton, 2005; Dayton \& Cornish, 2005). These surveys followed the National Vegetation Classification protocol (NVC, Rodwell, 2006). Species were recorded on the Domin scale in $2822 \mathrm{~m} \times 2 \mathrm{~m}$ quadrats, stratified by community type and covering the full range of topographical/environmental conditions. Because the data were collected in order to map the community types, the emphasis was on sampling representative vegetation rather than random sampling, resulting in some quadrats being close together. In order to reduce the impact of spatial autocorrelation on the subsequent models (Guisan \& Zimmermann, 2000), which has been found to be insignificant beyond $150 \mathrm{~m}$ (Fischer, 1990; Guisan et al., 1998) quadrats were removed from the data set at random so that no two quadrats were closer than $200 \mathrm{~m}$, leaving 213 quadrats for the analysis. The local models were tested on independent data from a survey of $1002 \mathrm{~m} \times 2 \mathrm{~m}$ quadrats in 2005. The 100 quadrats were positioned at the intersections of $100 \mathrm{~m}$ contours with 19 altitudinal transects ('gradsects'; see Guisan \& Zimmermann, 2000) at the Ben Lawers nature reserve. Transects were placed randomly, but ensuring that the full range of slope aspects was covered. Each transect was followed in the field using a compass and a quadrat was thrown randomly from the intersection with each $100 \mathrm{~m}$ contour, found using a GPS (Garmin eTrex Summit) with a barometric altimeter.

\section{Bioclimatic data}

The same five bioclimatic variables were used in macro, downscaled and local models in order to keep the modelling protocol as similar as possible between scales. These variables were: absolute minimum temperature $\left(T_{\min }\right)$, maximum annual temperature $\left(T_{\max }\right)$, growing degree days (GDD), soil moisture surplus (SMS) and soil moisture deficit (SMD). See Pearson et al. (2002) for the rationale behind and methods for creating these variables at the European and national scales. They were derived from gridded climatology data available at $0.5^{\circ}$ latitude/longitude resolution for Europe (Hulme et al., 1995) and both 50 and $5 \mathrm{~km}$ resolutions for the United Kingdom (Hulme et al., 2002). The same climate variables were derived for the study site at $50 \mathrm{~m}$ resolution, using a number of climatic datasets, as described below.

Temperature data at $5 \mathrm{~km}$ resolution were interpolated to $50 \mathrm{~m}$ resolution based upon the topography using the tave ARCGIS programme (see Zimmermann \& Kienast, 1999). First, a $50 \mathrm{~m}$ digital elevation model (DEM; Ordnance Survey/EDINA) of the study site was aggregated to $5 \mathrm{~km}$ resolution and the mean altitudes of the $5 \mathrm{~km}$ grid cells were used to derive linear regressions of monthly temperature on altitude (environmental lapse rates). The lapse rates showed seasonal variations around annual means of 8.6, 6.3 and $3.7^{\circ} \mathrm{C} \mathrm{km}^{-1}$ for maximum, mean and minimum temperatures, respectively, agreeing with previous published lapse rates for upland Britain (Harding, 1978). The regression intercepts (equivalent to the theoretical temperature at sea level) were added to the residuals and these values were then interpolated across the site and smoothed with a circular filter of $5 \mathrm{~km}$ radius. Finally, the interpolated surface was resampled to $50 \mathrm{~m}$ resolution and the altitudinal temperature gradient added back as the product of the lapse rates and altitude from the 50 m DEM (Zimmermann \& Kienast, 1999).

The soil moisture variables were created using a bucket model, based on the Penman equation (Pearson et al., 2002). The input variables to the model were soil water availability, precipitation, wind speed and solar radiation. Soil maps were obtained in electronic form or digitized from paper maps at 1:63360 and 1:50000 scale (Macaulay Institute for Soil Research, 1982, 1985). Available water capacity was assigned to each soil type based upon soil classification tables (MAFF, 1988). Gridded average precipitation at $1 \mathrm{~km}$ resolution was obtained for the study site from the UK's National 
Water Archive and resampled to $50 \mathrm{~m}$ resolution. Wind speed $10 \mathrm{~m}$ above the ground at $50 \mathrm{~m}$ resolution was obtained from a topographic wind model used in forestry (Bell et al., 1995). Solar radiation was generated using the MT-CLIM model (Thornton et al., 2000). The validity of this model was confirmed through comparison with global solar radiation data from two Met Office stations (Aviemore, $75 \mathrm{~km}$ to the north, and Eskdalemuir, $130 \mathrm{~km}$ south) and an automatic weather station (Didcot Instruments, Abingdon, UK) at $700 \mathrm{~m}$ a.s.l. at the study site (mean $r^{2}=0.67$ ).

Projected temperature and precipitation changes for the 2080s were added to the baseline climates according to two future scenarios in which global greenhouse gas emissions over the coming decades are either low or high. These follow the B1 and A1FI scenarios, respectively, of the Intergovernmental Panel on Climate Change (IPCC: www.ipcc.ch). The projected annual average temperature increases were 1.7 and $3.3^{\circ} \mathrm{C}$, respectively, while annual average precipitation decreases were $3.6 \%$ and $7 \%$, respectively. Climate changes were applied to the $50 \mathrm{~m}$ resolution bioclimate variables using scenarios at $5 \mathrm{~km}$ resolution, generated by the HadRM3 regional climate model (Hulme et al., 2002). These data were derived by applying $50 \mathrm{~km}$ resolution output from the HadRM3 regional climate model to the observed 1961-1990 baseline climate at $5 \mathrm{~km}$ resolution (Hulme et al., 2002). HadRM3 has a 20year history of development and has been carefully analysed and evaluated over many model generations (Hulme et al., 2002). The scenarios have been used in a number of national and regional climate impact studies in the United Kingdom (e.g. Berry et al., 2005; McEvoy et al., 2006).

\section{Bioclimate models}

The bioclimatic variables differed by orders of magnitude and so, before analysis, they were standardized to range between 0 and 1, based upon the minimum and maximum values. At the European extent, the species/ bioclimate data were split 70:30 at random into calibration and evaluation subsets (Fielding \& Bell, 1997). The local models were trained on data from the 213 quadrats and evaluated with the 100 independent quadrats. The species chosen were found in at least 10 quadrats in order to reduce errors associated with small sample sizes (Stockwell \& Peterson, 2002). Each quadrat was assigned to a $50 \mathrm{~m}$ grid box in order to extract values for the bioclimatic variables.

Generalized additive models (GAMs) were fitted to species presence/absence using the gam package in $\mathrm{R}(\mathrm{R}$ Development Core Team, 2005). GAMs are semiparametric extensions of generalized linear models (GLMs,
Hastie \& Tibshirani, 1990; Guisan et al., 2002). They are one of the most powerful techniques for bioclimate modelling (Araújo et al., 2005) and have performed well over a range of spatial scales (Thuiller et al., 2003a). Initially, univariate GAMs with 4 degrees of freedom were used to investigate the importance of each independent variable and determine an appropriate degree of smoothing. Variables showing significant relationships with the presence/absence of the species were then entered into a multivariate model selection process, as described by Wintle et al. (2005). Variable selection was based upon Akaike's Information Criterion (AIC, Akaike, 1973).

Models were evaluated using the area under the curve (AUC) of receiver operating characteristic (ROC) plots (Swets, 1988) and Miller's calibration statistics (Pearce \& Ferrier, 2000; Wintle et al., 2005). Species with low prevalence (e.g. restricted range species) can be difficult to model (McPherson et al., 2004; Liu et al., 2005; Jiménez-Valverde \& Lobo, 2006). This problem was dealt with in different ways at the two scales, reflecting the 7228 observations across Europe compared with only 313 observations across the study site. Where the calibration statistics indicated poor European model fit, the data were split so that $70 \%$ of occupied cells were assigned to the training dataset and the remaining $30 \%$ to the test set. Where a species' prevalence was too low for the local model to be trained and tested on separate data, both training and testing datasets were pooled for model creation. A resampling method was then used to give bootstrap estimates of model goodness of fit (Ferrier \& Watson, 1997; Wintle et al., 2005). The predicted suitability surfaces from the GAMs were converted to binomial presence/absence using a threshold value (Pfair) which balanced errors of commission (false positive predictions) and omission (false negatives, Bonn \& Schröder, 2001; Thuiller et al., $2003 \mathrm{~b})$. At the local scale, several drivers of species distribution were missing from the model, such as snow cover, water resurgence and soil disturbance. So maximising the agreement between the observed and predicted distributions may not be appropriate (Pearce \& Ferrier, 2000). As a comparison, we also used a threshold which minimised omission errors, thereby encapsulating more of the potential environmental space of each species (Pearson et al., 2004). The overall results from the two thresholds were similar and so only the results of the Pfair method are presented.

The macro models were projected using observed baseline (1961-1990) climate data at both 50 and $5 \mathrm{~km}$ resolution to predict the current suitable climate space across Great Britain. They were then projected under the climate change scenarios to estimate the re-distribution of this space in the future. The entire realized climatic niche of each species should be captured by 
training the models across Europe. The climate change scenarios for Britain do not exceed the observed range of climates currently found across Europe.

Predictions of currently suitable climate space were compared with observed distributions, downloaded from the National Biodiversity Network (NBN) Gateway (www.searchNBN.net). These observations were aggregated from their 10 to $50 \mathrm{~km}$ resolution for comparison with the macro model predictions. The downscaled predictions were aggregated to the $10 \mathrm{~km}$ grid by taking the mean suitability of four adjacent $5 \mathrm{~km}$ grid boxes and then applying the ROC threshold. The predicted and observed distributions were then compared using the Jaccard coefficient of similarity, as in a previous scale-comparison study (Araújo et al., 2005).

The local models were used to project the future potential distributions of each species and the suitability of $50 \mathrm{~m}$ grid cells was compared with the suitability of the corresponding 50 and $5 \mathrm{~km}$ grid cells from the macro and downscaled models, respectively. For example, a macro model could project that a $50 \mathrm{~km}$ grid cell and its constituent $5 \mathrm{~km}$ cells become unsuitable, whereas a local model could project that some areas $(50 \mathrm{~m}$ cells) within the site remain suitable. The study site was encompassed by eighteen $5 \mathrm{~km}$ grid cells of the downscaled model. However, the $50 \mathrm{~km}$ grid was derived directly from HadRM3 output, which was not aligned with the British National Grid format of the $5 \mathrm{~km}$ and $50 \mathrm{~m}$ grids. The site was located at the north-eastern corner of one $50 \mathrm{~km}$ grid cell and spilled over into the neighbouring cell to the north. It was not possible to obtain local survey data for all mountains within the main $50 \mathrm{~km}$ grid cell. However, the mountains surveyed were among the highest within this cell and so the results should be representative of the cell as a whole.

The local models were created using data from quadrats ranging in altitude from 200 to $1100 \mathrm{~m}$. The lower altitudinal limits of lowland species would, therefore, not have been captured and the projections for this group of species should, therefore, be read with caution. However, the altitudinal distributions of montane species were adequately sampled and these models should be more robust under climate change scenarios. To avoid extrapolation beyond models' training experience we masked out lower altitudes which were projected to experience future climates which did not currently occur in the study site (Guisan \& Theurillat, 2000).

\section{Results}

\section{Fitting bioclimate models at European and local scales}

Models fitted to European distributions had a high goodness of fit (mean AUC $=0.98, \mathrm{SD}=0.01$ ) and were well calibrated (mean Miller's calibration slope $=1.06$, $\mathrm{SD}=0.11)$. In contrast, the local models had lower goodness of fit (mean AUC $=0.78, \mathrm{SD}=0.11$ ) and were less well calibrated (Miller's calibration slope $=0.88$, $\mathrm{SD}=0.86$ ). Model performance statistics for all species are given in Appendix A. As indicated by their high level of accuracy, the European models captured the climatic envelope of each species. However, the lower accuracy of the local models indicates that the climatic variables did not fully explain the distributions of the species across the study site.

\section{Performance of macro and downscaled model predictions}

The macro models were projected onto a $50 \mathrm{~km}$ grid across Great Britain and also downscaled to a $5 \mathrm{~km}$ resolution. The Jaccard coefficients of similarity between macro $(50 \mathrm{~km})$ predictions and national observations aggregated up to the same resolution (median $S_{\mathrm{j}}=77 \%$; lower quartile $=60 \%$; upper quartile $=91 \%$ ) indicate that the predictions were reliable, as would be expected given the high goodness of fit of these models to European distributions. However, by aggregating the observational data to a coarser resolution the percentage prevalence increased, thereby masking commission errors (false presences). Looking at montane and lowland species separately, montane species distributions were found to be overestimated, as illustrated in Fig. 2c for Carex bigelowii. This resulted in a lower agreement with observations compared with the lowland species (Table 1).

The downscaled predictions showed a lower agreement with observations (median $S_{\mathrm{j}}=51 \%$; lower quartile $=27 \%$; upper quartile $=69 \%$ ) than those of the macro models, reflecting the increased likelihood of commission errors at this resolution. Montane species were again over-predicted compared with lowland species (Fig. 2), resulting in lower similarity scores (Table 1).

\section{Climate change projections at national and local scales}

The models trained on the European species distributions were used to project the suitable climate space for each species across Great Britain at 50 and $5 \mathrm{~km}$ resolution under low (B1) and high (A1FI) warming scenarios for the 2080s. Widespread species, such as Potentilla erecta (Fig. 2a), tended to retain suitable climate space across Britain. However, the heathland species, Calluna vulgaris, lost suitable space in the south-east of the country under the high scenario (Fig. 2b). In contrast, all montane species lost climate space in the southern and lower altitude parts of their British ranges (Fig. 2c). 


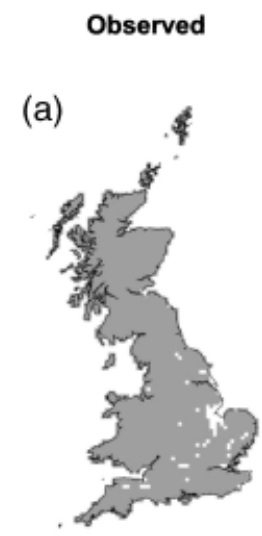

Potentilla erecta

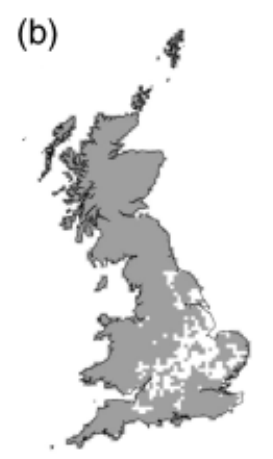

Calluna vulgaris

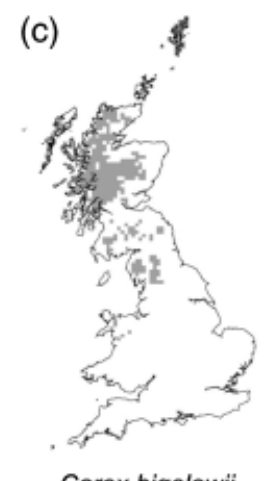

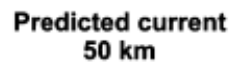

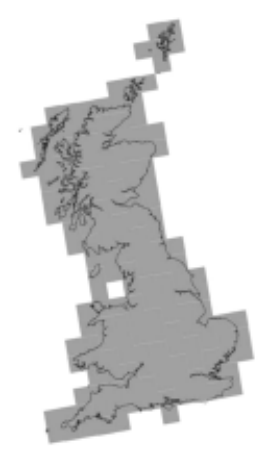

$S_{\mathrm{j}}=1.00$
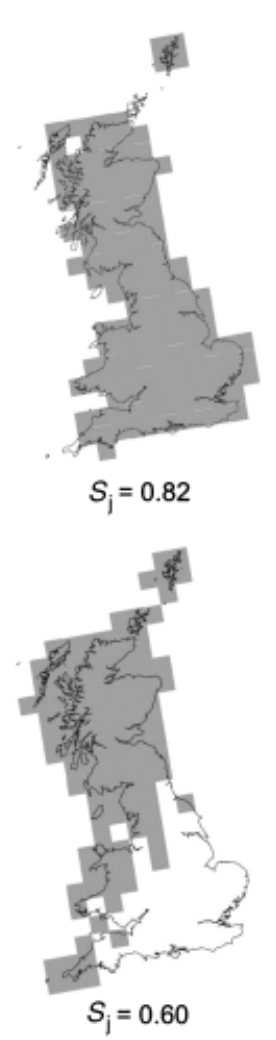
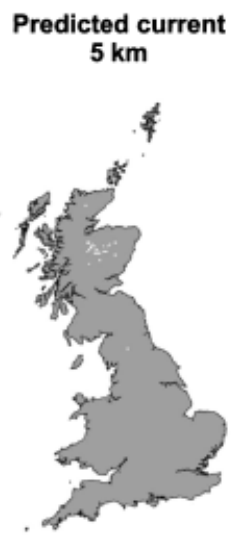

$S_{\mathrm{j}}=0.96$
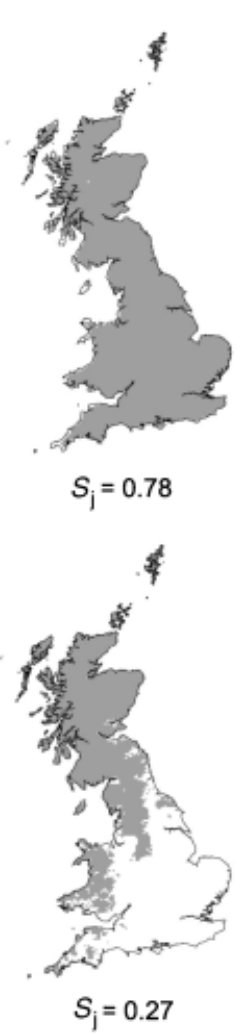

\section{Projected 2080s \\ $50 \mathrm{~km} \quad 5 \mathrm{~km}$}
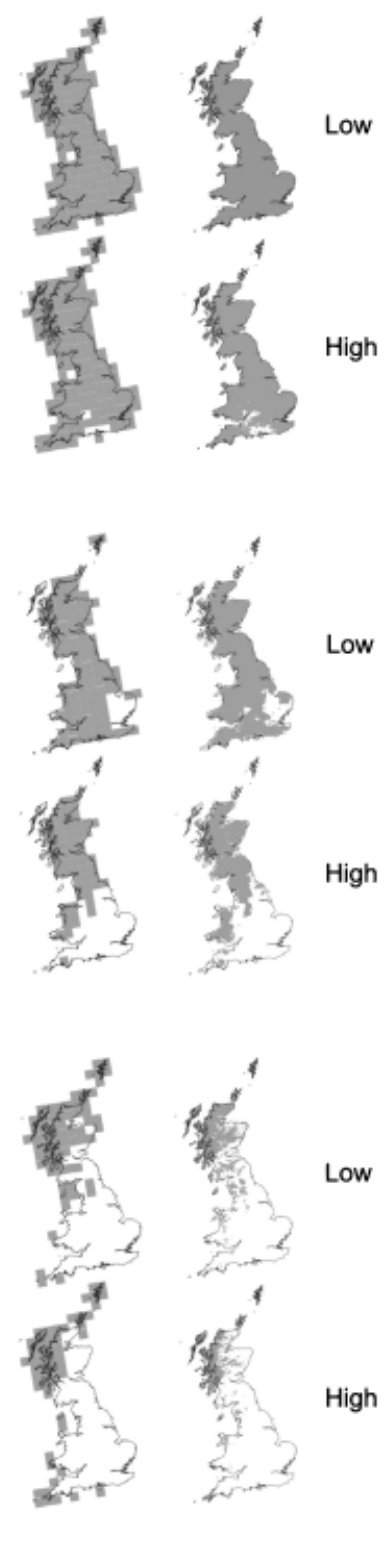

Fig. 2 Observed (far left) and predicted distributions of three plant species in Great Britain: (a) Potentilla erecta, (b) Calluna vulgaris and (c) Carex bigelowii. Predictions are presented for both the original $(50 \mathrm{~km} \times 50 \mathrm{~km}$ grid) and the downscaled resolution $(5 \mathrm{~km} \times 5 \mathrm{~km}$ grid). The degree of agreement between observed and predicted distributions is given by the Jaccard coefficient $\left(S_{\mathrm{j}}\right)$. Future suitable climate space projections at both resolutions and under low and high climate change scenarios are given for each species on the right.

Focusing on the extent of the mountain study site, lowland species were projected to retain suitable climate space by both macro and downscaled models, reflecting the overall national pattern (Table 2). However, montane species also tended to retain some suitable climate space. Under the high warming scenario, the macro model for a single montane species, Festuca vivipara, projected loss of suitable climate space from both the northern and southern $50 \mathrm{~km}$ grid cells overlapping the study site (Table 2, Fig. 3a). Also under a high warming scenario, the macro model for another montane species, Thalictrum alpinum, projected unsuitability of the southern $50 \mathrm{~km}$ grid cell, but the higher altitude cell to the north remained suitable.

The local models projected that the area of suitable climate space for lowland species would increase and 
Table 1 Agreement between observed current species distributions across Great Britain and predicted distributions from macro $(50 \mathrm{~km}$ resolution) and downscaled (5 $\mathrm{km}$ resolution) bioclimate models

\begin{tabular}{lcc}
\hline & \multicolumn{2}{l}{$\begin{array}{l}\text { Median Jaccard coefficient of } \\
\text { similarity (\%) }\end{array}$} \\
\cline { 2 - 3 } & Macro & Downscaled \\
\hline Montane $(n=10)$ & 62 & 26 \\
Lowland $(n=10)$ & 91 & 70 \\
\hline
\end{tabular}

Table 2 Number of species (out of 10) projected to retain suitable climate space at the study site according to macro, downscaled and local bioclimate models under two climate change scenarios for the 2080s

\begin{tabular}{|c|c|c|c|c|c|c|}
\hline & \multicolumn{3}{|c|}{ Low scenario } & \multicolumn{3}{|c|}{ High scenario } \\
\hline & Local & Macro & Downscaled & Local & Macro & Downscaled \\
\hline Lowland & 10 & 10 & 10 & 10 & 10 & 10 \\
\hline Montane & 3 & 10 & 10 & 2 & 9 & 10 \\
\hline
\end{tabular}

shift up the mountainsides, agreeing with the macro and downscaled model projections. In contrast, the local models projected loss of all suitable climate space for most montane species (Table 2). Three montane species - F. vivipara (Fig. 3a), T. alpinum and Selaginella selaginoides - retained some suitable climate space on mountain summits under the low scenario and the latter two species did so under the high scenario. Local, macro and downscaled model projections for two montane species at the site are compared in Fig. 3. The pattern of local 'loss' but macro 'retention' shown by Alchemilla alpina (Fig. 3b) was typical of montane species.

\section{Comparison of thermal tolerance of montane species across scales}

Figure 4a shows a weak but significant relationship between the estimated thermal limits of montane species at each scale of observation (mean Pearson's $r=0.65, P<0.05$ ). However, it also shows that the estimated thermal tolerance increased with spatial scale, i.e. the montane species were found at successively warmer climates when moving from local to British and, finally, European scales. Increasing spatial scale involves increases in both extent and grain (Wiens, 2002). Holding spatial extent constant by focusing on distributions across Great Britain, grain size had no consistent effect on estimated thermal tolerance when comparing 10 and $50 \mathrm{~km}$ resolution data (Fig. 4b). This indicates that, at least across Great Britain, climate data at $50 \mathrm{~km}$ resolution were no more biased towards warmer temperatures than $10 \mathrm{~km}$ data. This is supported by the congruence of the macro $(50 \mathrm{~km})$ and downscaled $(10 \mathrm{~km})$ predictions of montane species' current distributions, illustrated in Fig. 2. If mountain climates were better discriminated by the $10 \mathrm{~km}$ climate data we would have expected the downscaled predictions to have given better agreement with observations than the macro models, but this was not the case.

Although its influence on the relationships was not great (mean Cook's $d=0.53$ ), F. vivipara was excluded as an outlier from the regression analysis (Fig. 4a). The estimated temperatures at its warm margins at the three scales were more similar than in other species.

\section{Discussion}

Both biotic and algorithmic errors in bioclimate models (Fielding \& Bell, 1997) could arise through the choice of spatial scale of analysis. For instance, the climatic tolerance of a species across its continental range may not be matched at smaller spatial scales, due to the local adaptation of populations (Davis \& Shaw, 2001). Also, macro scale bioclimate models may be affected by the coarse resolution of the data. As discussed by Dungan et al. (2002), the latter situation is an example of the 'modifiable areal unit problem' (MAUP; Openshaw, 1984). As such, a 'scale problem' arises when spatial data are aggregated into successively larger areal units, leading to different data values and inferences at each level of aggregation (Gehlke \& Biehl, 1934). This problem will be more important in heterogeneous than homogeneous study areas (Wiens, 1989). Thus, creating climate data at a coarse resolution averages out the variability found in mountainous terrain and may bias the data towards the climates found at more common, lower altitudes. This effect has been recognised in research on the relationship between macro scale species richness gradients and available water and energy. Such coarse resolution studies have typically underpredicted species richness in areas of high topographic heterogeneity (O'Brien et al., 2000; Qian \& Ricklefs, 2000; Rahbek \& Graves, 2001) and the inclusion of a topographic relief index has improved the predictions (e.g. O'Brien et al., 2000; Davies et al., 2007).

It follows that macro scale bioclimate models could also give poor predictions for montane species. However, the macro models based on species' European distributions were of high discriminatory power (mean AUC $=0.98$ ) and showed no variation in accuracy according to whether species were montane or more 
(a)

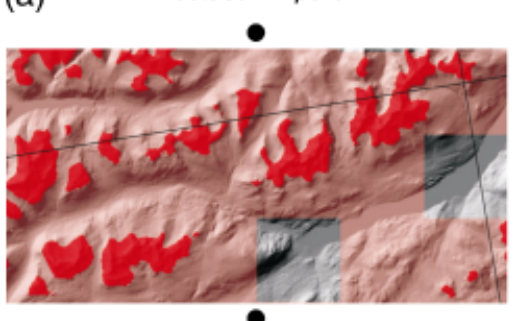

○

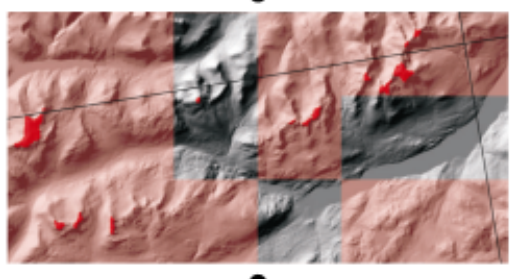

-

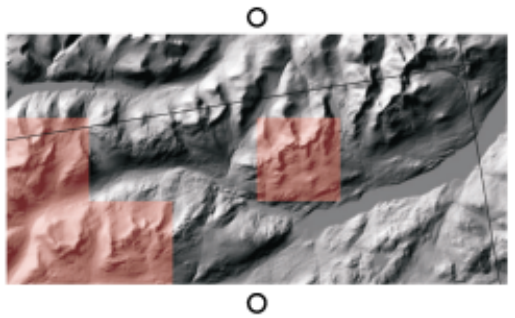

(b) Alchemilla alpina
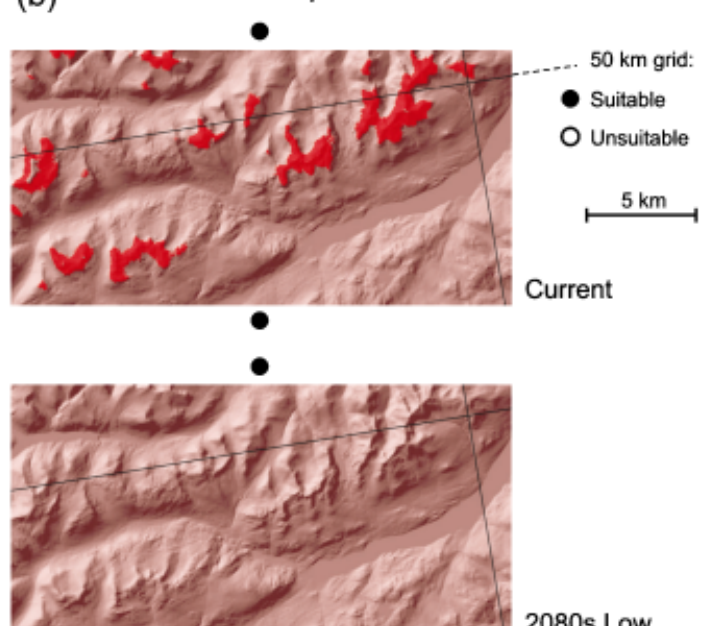

2080s Low

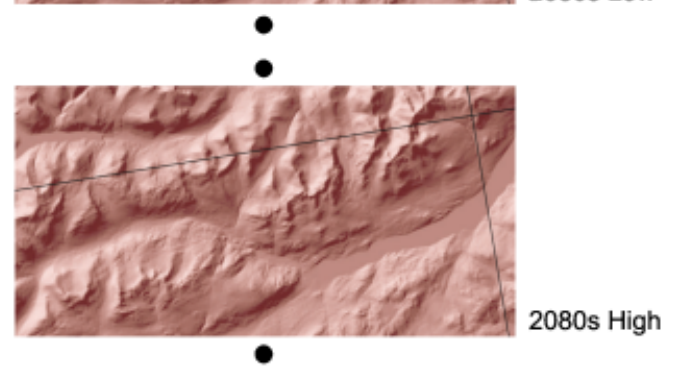

Fig. 3 Comparison of predicted current and projected future suitable climate space for (a) Festuca vivipara and (b) Alchemilla alpina under low and high climate change scenarios. Suitable areas are shown in red for the local models, pink for the downscaled (5 km $\times 5 \mathrm{~km})$ models and by circles for the suitability of northern and southern $50 \mathrm{~km}$ grid cells of the macro model.
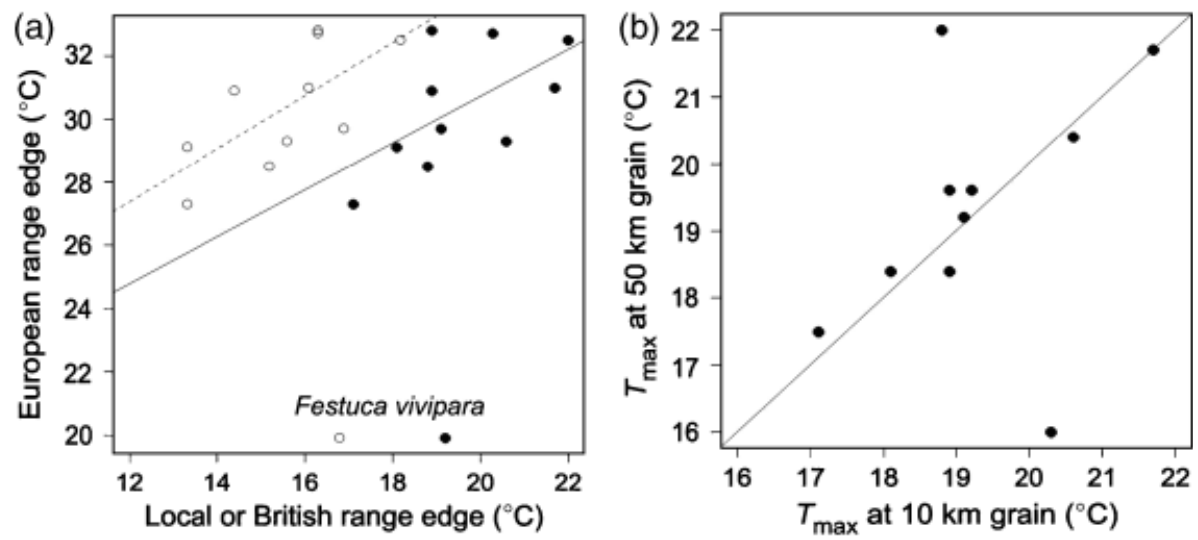

Fig. 4 (a) Temperature maxima observed at warm range margins for ten montane species at the European scale vs. the local (mountain range; open circles) and British (closed circles) scales. Note the different axis scales. Regression lines were fitted with Festuca vivipara omitted as an outlier (mean Cook's $d=0.53$ ). (i) European vs. local (dashed): $y=17.26+0.84 x, \mathrm{df}=8, r^{2}=0.48, P=0.03$; (ii) European vs. British: $y=15.86+0.74 x, \mathrm{df}=8, r^{2}=0.37, P=0.06$. (b) Comparison of temperature maxima observed at warm range margins of montane species at $50 \mathrm{~km} \times 50 \mathrm{~km}$ and $10 \mathrm{~km} \times 10 \mathrm{~km}$ grid resolutions within Great Britain. Diagonal line represents $y=x$.

widespread. Indeed, some authors have suggested that, due to their concise, distinct distributions, narrowranging species might be expected to have more predictable niches, facilitating more accurate models
(Stockwell \& Peterson, 2002; Guisan \& Hofer, 2003; McPherson et al., 2004; Luoto et al., 2005). For example, Segurado \& Araújo (2004) found that widespread herptile species in Portugal had greater overall errors, but 
the amount of unexplained variation in the climatic niches (measured by the proportion of false negative predictions) of this group was not greater than for more restricted species. Araújo \& Williams (2000) did find that widespread species had higher proportions of false negatives than restricted-range species, while restricted species had higher levels of false positive predictions. We also found that restricted (i.e. montane) species had higher levels of false positive predictions when comparing predicted and observed British distributions (illustrated in Fig. 2c). Thus, although macro models for montane species performed well overall across Europe, they overestimated occupancy within Britain. This was because the macro models were calibrated with estimated thermal tolerances that were much greater than those observed at British and local scales (Fig. 4a).

The greater thermal tolerance at the European scale may have been caused by the scale problem created by topography (Welk \& Bruelheide, 2006). Coarse resolution climate data averaged over large areas are more representative of lower, warmer altitudes than the highaltitude locations of montane species. This, in turn, can generate systematic errors in the bioclimate models (Barry \& Elith, 2006), resulting in false predictions of montane species occurrence at lower, warmer altitudes. When holding spatial extent constant by focusing on Britain, the aggregation of climate and species data at a $50 \mathrm{~km}$ resolution did not lead to overestimation of thermal tolerance compared with $10 \mathrm{~km}$ data (Fig. 4b) (i.e. grain had no effect within Britain). This result is supported by Guisan et al. (2007), who found no effect of grain size on model performance. Because Britain's mountains are relatively low, changing grain size from $10 \mathrm{~km} \times 10 \mathrm{~km}$ to $50 \mathrm{~km} \times 50 \mathrm{~km}$ would not be expected to have a significant impact on the climate statistics. This is supported by Nogués-Bravo \& Araújo (2006), who showed that at large spatial extents and coarse grains, variations in DEM resolution did not result in very large changes in estimated surface area, implying a limited effect of grain size on topographic and, hence, climatic heterogeneity. However, they showed that the effect was greater when using a fine resolution DEM in a high mountain region (Nogués-Bravo \& Araújo, 2006). Taken together, these results suggest that the bias in estimated thermal tolerance was caused by the difference between the local climates experienced by mountain plants and gridded climate data in the high mountain regions of continental Europe, such as the Alps and Pyrenees. Detailed investigation of within-cell topographic heterogeneity across montane species' geographical ranges would help to quantify the systematic errors in estimated thermal tolerance due to the use of coarse-grained data.
Another possible explanation for the results is that British populations may only tolerate a more limited, cooler climate than the global populations of each species. If this were the case, local models would be expected to project greater warming impacts on local populations than macro models would project for the species entire European distribution, as previously suggested (Davis \& Shaw, 2001; Hampe, 2004; Harte et al., 2004). Such ecotypic differences have been found between Arctic and alpine populations of several plant species (Billings \& Mooney, 1968), as well as between populations at different altitudes (Körner, 1999; Giménez-Benavides et al., 2007). However, ecotypic variation may not be universal (e.g. Morecroft \& Woodward, 1996), particularly among species with clonal reproduction. Nevertheless, there is a need to explore the local and regional adaptations of montane species in more detail. For example, tests of the transferability of local models among mountain sites may reveal geographical differences in climatic niche (Randin et al., 2006). Reciprocal transplantations and growth chamber experiments could be conducted on plants from different mountain ranges to further investigate the climatic tolerances of different life-stages of a species.

Two other sources of error may have also led to commission errors in predictions across Great Britain by the macro models. First, an important unmeasured but potentially explanatory variable may have reduced the predictive power. The low numbers of omission errors (false negative predictions), contrasted against the relatively large number of commission errors indicate that the full climatic range of each species was indeed encapsulated by the macro models (Pearce \& Ferrier, 2000; Anderson et al., 2003). However, the false positive predictions for montane species may in part reflect the role of land cover in creating unsuitable habitat patches in climatically suitable areas. Although land cover is not an important factor in continental scale models (Thuiller et al., 2004a), previous downscaling studies have found it to affect species distributions at landscape scales (Pearson et al., 2004; Araújo et al., 2005). Thus including this variable in the downscaling process may have improved the predictions for some montane species in this study. However, Pearson et al. (2004) analysed downscaling results for four species, including two associated with montane habitats, one of which, Salix herbacea, was also modelled in the present study. They found that the addition of land cover did not significantly improve predictions for these two species. Their explanation was that at the $10 \mathrm{~km}$ resolution of their study nearly all climatically suitable montane grid cells are likely to contain some suitable land cover types, reducing the importance of land cover at this resolution (Pearson et al., 2004). Furthermore, at this 
resolution, land cover might be more important for widespread, lowland species as habitat modification through urbanization and agriculture has been more intense in lowland areas (Warren et al., 2001; Conrad et al., 2006).

The second source of commission errors could be the use of atlas range maps to derive species occurrence inputs to the macro models. Species ranges are more porous than may be perceived from the contiguous surfaces given in some atlases (Brown et al., 1996; Hurlbert \& White, 2005). This may then result in false presences entering the model, artificially enlarging the thermal tolerance of restricted species. Although efforts were made to limit this effect by cross-checking several atlases and using the most recent information in the Atlas Florae Europaeae (Jalas \& Suominen, 1972-1991) wherever possible, it may still have been a factor.

The bias in the macro models had consequences for their projections under future climate change scenarios when compared with local models at the study site. The local and macro models agreed that lowland species would retain suitable climate space. However, the macro models projected that montane species would also retain climate space, while the local models projected their loss (Table 2, Fig. 3b). Thus models trained on continental species distributions appeared to underestimate the potential impacts of climate change at this Scottish site.

Previous coarse-grained studies have highlighted the vulnerability of British and European montane floras to climate change (e.g. Bakkenes et al., 2002; Berry et al., 2002; Thuiller et al., 2005). However, it has been suggested that the varied topography of mountain regions will create microclimatic refugia for species to persist even though the macroclimate, as depicted in the coarse grid, becomes unsuitable (Noss, 2001; Thuiller et al., 2005). Although tests at other mountain regions are required to determine the generality of our results, they suggest that such microclimatic refugia might not be as prevalent as hoped.

Although macro models appeared to give inaccurate predictions for montane species we do not suggest that they should be abandoned in favour of local models. The latter suffered from their own inaccuracies, and hence predictive uncertainties due to: the low prevalence of montane species within the local dataset; the generation of fine resolution environmental variables; the effects of unmeasured variables such as snow cover, soil chemistry and water resurgence on local species distributions (Guisan \& Theurillat, 2000); the uncertainty of climate change projections for any one location; and the potential creation of truncated species response curves since the full realized niche may not be observed at a local scale (Huston, 2002; Thuiller et al., 2004b). The field survey did not sample below $200 \mathrm{~m}$ a.s.l. and so the distributions of lowland species would not have been completely sampled along the altitudinal gradient, resulting in truncated response curves for this group. Montane species should have suffered less from this effect. However, if present, such an effect would be expected to increase the projected loss of suitable local climate space, thereby overestimating the impacts of climatic warming. Comparisons of modelled niche breadth of populations in different mountain ranges would help to clarify this issue.

Downscaling the macro models to $5 \mathrm{~km}$ resolution did not yield improved predictions of montane species' current distributions across Great Britain. This might be expected because the downscaling process involved simply applying the macro models directly onto a finer resolution bioclimate grid. In a study of weed distributions in Great Britain, Collingham et al. (2000) also obtained poor results when reprojecting models from $10 \mathrm{~km} \times 10 \mathrm{~km}$ to $2 \mathrm{~km} \times 2 \mathrm{~km}$ resolution. They concluded that focusing down from large to small extents would be appropriate if data resolution were held constant (Collingham et al., 2000). Achieving this in the context of bioclimate modelling would be difficult because fine resolution species distribution and climate data are not available for continental extents. Hierarchical modelling frameworks have been proposed as a solution to this scaling problem (Guisan \& Thuiller, 2005), by taking advantage of the data resolutions available at different extents while accounting for the hierarchical nature of the drivers of species distributions across spatial scales (Mackey \& Lindenmayer, 2001). Such a framework has enabled the incorporation of information on local sampling intensity (Gelfand et al., 2005) and land cover (Pearson et al., 2004; Araújo et al., 2005), as well as expert knowledge (McPherson et al., 2006) into distribution models, although results have been mixed.

Hierarchical models could be developed to include local estimates of species' thermal tolerances, as well as fine resolution land cover and topographically driven climate data, in order to better project the macro models to the local scale. Biotic interactions, which have been difficult to factor into bioclimate models, become relatively more prominent at fine resolutions and so could be incorporated at the local scale (Pearson \& Dawson, 2003). Plant-plant interactions may change from facilitative to more competitive as the climate warms (Brooker, 2006). In this context, species dispersal ability becomes relevant, because it is the uphill migration of competitive low-altitude species which may ultimately result in the loss of suitable climate space for montane species. In this study, migration was assumed to be 
universal across the model grids, at both macro and local scales. Dispersal could be incorporated into models if adequate data become available. Such developments are important if model projections are to be of use to local and regional conservation strategies.

\section{Conclusions}

This study found that European scale bioclimate models overestimated the thermal tolerance of local populations of montane species, resulting in underestimation of the potential impacts of climate change relative to models trained at the local scale of a mountain range. We propose that this problem arose through a bias against the cooler climates found in mountains due to the aggregation of climate data at coarse resolutions and, potentially, a disregard of the intraspecific adaptations of montane species to the local environment. These findings indicate that previous studies estimating the threat of climate change to montane species based on coarse bioclimate models may have been conservative.

\section{Acknowledgements}

We thank the National Trust for Scotland and Scottish Natural Heritage for access to the study site and data. Climate data were obtained from the British Atmospheric Data Centre, National Water Archive, UK Climate Impacts Programme and M. Browne. Soil data were obtained from the Macaulay Institute, with interpretative help from A. Lilley. B. Gardiner of Forest Research provided wind data. We acknowledge the numerous volunteer recorders who contributed data to the NBN Gateway. A. Dessiter modified MT-CLIM. We acknowledge the invaluable field assistance of J. McCathie, J. Williams, R. Smith and R. Wood. We are indebted to D. Mardon, A. Warwick, P. Harrison, R. Callow, W. Angus and G. Angus, and R. Thomas and J. Thomas for advice and guidance. D. Benham, M. Taylor and G. Wickes gave technical support. This research forms part of the EUROMONT project, co-ordinated by A. Guisan, and MT benefited from the discussions and ideas of workshops held in April and December 2006 at the University of Lausanne. A. Guisan and two anonymous reviewers gave valuable comments on the manuscript. M. T. was supported by a NERC studentship.

\section{References}

Akaike H (1973) Information theory as an extension of the maximum likelihood principle. In: 2nd International Symposium on Information Theory (eds Petrov BN, Csaksi F), pp. 267-281. Akademiai Kiado, Budapest, Hungary.

Anderson RP, Lew D, Peterson AT (2003) Evaluating predictive models of species' distributions: criteria for selecting optimal models. Ecological Modelling, 162, 211-232.

Araújo MB, Guisan A (2006) Five (or so) challenges for species distribution modelling. Journal of Biogeography, 33, 1677-1688.
Araújo MB, New M (2007) Ensemble forecasting of species distributions. Trends in Ecology and Evolution, 22, 42-47.

Araújo MB, Pearson RG (2005) Equilibrium of species' distributions with climate. Ecography, 28, 693-695.

Araújo MB, Thuiller W, Williams PH, Reginster I (2005) Downscaling European species atlas distributions to a finer resolution: implications for conservation planning. Global Ecology and Biogeography, 14, 17-30.

Araújo MB, Williams PH (2000) Selecting areas for species persistence using occurrence data. Biological Conservation, 96, 331-345.

Bakkenes M, Alkemade JRM, Ihle F, Leemans R, Latour JB (2002) Assessing effects of forecasted climate change on the diversity and distribution of European higher plants for 2050. Global Change Biology, 8, 390-407.

Barry S, Elith J (2006) Error and uncertainty in habitat models. Journal of Applied Ecology, 43, 413-423.

Beaumont LJ, Pitman AJ, Poulsen M, Hughes L (2007) Where will species go? Incorporating new advances in climate modelling into projections of species distributions. Global Change Biology, 13, 1368-1385.

Bell PD, Quine CP, Wright JA (1995) The use of digital terrain models to calculate windiness scores for the windthrow hazard classification. Scottish Forestry, 49, 217.

Berry PM, Dawson TP, Harrison PA, Pearson R, Butt N (2003) The sensitivity and vulnerability of terrestrial habitats and species in Britain and Ireland to climatic change. Journal for Nature Conservation, 11, 15-23.

Berry PM, Dawson TP, Harrison PA, Pearson RG (2002) Modelling potential impacts of climate change on the bioclimatic envelope of species in Britain and Ireland. Global Ecology and Biogeography, 11, 453-462.

Berry PM, Harrison PA, Dawson TP, Walmsley CA (2005) Monarch 2: modelling natural resource responses to climate change. United Kingdom Climate Impacts Programme, Oxford, UK.

Billings WD, Mooney HA (1968) The ecology of Arctic and Alpine plants. Biological Reviews of the Cambridge Philosophical Society, 43, 481-529.

Bonn A, Schröder B (2001) Habitat models and their transfer for single and multi-species groups: a case study of carabids in an alluvial forest. Ecography, 24, 483-496.

Botkin DB, Saxe H, Araújo MB et al. (2007) Forecasting the effects of global warming on biodiversity. Bioscience, 57, 227-236.

Brooker RW (2006) Plant-plant interactions and environmental change. New Phytologist, 171, 271-284.

Brown JH, Stevens GC, Kaufman DM (1996) The geographic range: size, shape, boundaries, and internal structure. Annual Review of Ecology and Systematics, 27, 597-623.

Collingham YC, Wadsworth RA, Willis SG, Huntley B, Hulme PE (2000) Predicting the spatial distribution of alien riparian species: issues of spatial scale and extent. Journal of Applied Ecology, 37, 13-27.

Conrad KF, Warren MS, Fox R, Parsons MS, Woiwood IP (2006) Rapid declines of common, widespread British moths provide evidence of an insect biodiversity crisis. Biological Conservation, 132, 279-291.

Cornish C, Dayton N (2005) NVC Survey of Beinn Heasgarnich SSSI and cSAC (Stirling). Quadrat Scotland, Argyll, UK. 
Davies RG, Orme CDL, Storch D et al. (2007) Topography, energy and the global distribution of bird species richness. Proceedings of the Royal Society B: Biological Sciences, 274, 1189-1197.

Davis AJ, Jenkinson LS, Lawton JH, Shorrocks B, Wood S (1998) Making mistakes when predicting shifts in species range in response to global warming. Nature, 391, 783-786.

Davis MB, Shaw RG (2001) Range shifts and adaptive responses to Quaternary climate change. Science, 292, 673-679.

Dayton N, Cornish C (2005) NVC Survey of Meall na Samnha SSSI and $C S A C$ (Stirling). Quadrat Scotland, Argyll, UK.

Dirnböck T, Dullinger S, Grabherr G (2003) A regional impact assessment of climate and land-use change on alpine vegetation. Journal of Biogeography, 30, 401-417.

Dungan JL, Perry JN, Dale MRT et al. (2002) A balanced view of scale in spatial statistical analysis. Ecography, 25, 626-640.

Elith J, Burgman MA, Regan HM (2002) Mapping epistemic uncertainties and vague concepts in predictions of species distribution. Ecological Modelling, 157, 313-329.

Elith J, Graham CH, Anderson RP et al. (2006) Novel methods improve prediction of species' distributions from occurrence data. Ecography, 29, 129-151.

Ferrier S, Watson G (1997) An evaluation of the effectiveness of environmental surrogates and modelling techniques in predicting the distribution of biological diversity. http://www.ea.gov.au/bio diversity/publications/technical/surrogates/pubs/surrogates. pdf. Environment Australia, Canberra.

Fielding AH, Bell JF (1997) A review of methods for the assessment of prediction errors in conservation presence/absence models. Environmental Conservation, 24, 38-49.

Fischer HS (1990) Simulating the distribution of plant communities in an alpine landscape. Coenoses, 5, 37-43.

Gavin DG, Hu FS (2006) Spatial variation of climatic and nonclimatic controls on species distribution: the range limit of Tsuga heterophylla. Journal of Biogeography, 33, 1384-1396.

Gehlke C, Biehl K (1934) Certain effects of grouping upon the size of the correlation coefficient in census tract material. Journal of American Statistical Association, 29, 169-170.

Gelfand AE, Schmidt AM, Wu S, Silander JA, Latimer A, Rebelo AG (2005) Modelling species diversity through species level hierarchical modelling. Journal of the Royal Statistical Society Series C-Applied Statistics, 54, 1-20.

Giménez-Benavides L, Escudero A, Iriondo JM (2007) Local adaptation enhances seedling recruitment along an altitudinal gradient in a high mountain Mediterranean plant. Annals of Botany, 99, 723-734.

Guisan A, Edwards J, Thomas C, Hastie T (2002) Generalized linear and generalized additive models in studies of species distributions: setting the scene. Ecological Modelling, 157, 89-100.

Guisan A, Graham CH, Elith J, Huettmann F (2007) Sensitivity of predictive species distribution models to change in grain size. Diversity and Distributions, 13, 332-340.

Guisan A, Hofer U (2003) Predicting reptile distributions at the mesoscale: relation to climate and topography. Journal of Biogeography, 30, 1233-1243.

Guisan A, Theurillat J-P (2000) Equilibrium modeling of alpine plant distribution: how far can we go? Phytocoenologia, 30, 353384.
Guisan A, Theurillat J-P, Kienast F (1998) Predicting the potential distribution of plant species in an alpine environment. Journal of Vegetation Science, 9, 65-74.

Guisan A, Thuiller W (2005) Predicting species distribution: offering more than simple habitat models. Ecology Letters, 8, 993-1009.

Guisan A, Zimmermann NE (2000) Predictive habitat distribution models in ecology. Ecological Modelling, 135, 147-186.

Hampe A (2004) Bioclimate envelope models: what they detect and what they hide. Global Ecology and Biogeography, 13, 469-471.

Harding RJ (1978) The variation of the altitudinal gradient of temperature within the British Isles. Geografiska Annaler, 60, $43-49$.

Harte J, Ostling A, Green JL, Kinzig A (2004) Biodiversity conservation - climate change and extinction risk. Nature, 430, doi: $10.1038 /$ nature02718.

Harte J, Shaw R (1995) Shifting dominance within a montane vegetation community: results of a climate-warming experiment. Science, 267, 876-880.

Hastie T, Tibshirani R (1990) Generalized Additive Models. Chapman and Hall, London.

Higgins PAT, Harte J (2006) Biophysical and biogeochemical responses to climate change depend on dispersal and migration. Bioscience, 56, 407-417.

Hulme M, Conway D, Jones PD, Jiang T, Barrow EM, Turney C (1995) Construction of a 1961-1990 European climatology for climate change modelling and impact applications. International Journal of Climatology, 15, 1333-1363.

Hulme M, Jenkins GJ, Lu X et al. (2002) Climate Change Scenarios for the United Kingdom: the UKCIP02 Scientific Report. Tyndall Centre for Climate Change Research, School of Environmental Sciences, University of East Anglia, Norwich, UK.

Hultén E (1962) The Circumpolar Plants I. Vascular Cryptogams, Conifers and Monocotyledons. Almqvist \& Wiksell, Stockholm.

Hultén E (1971) The Circumpolar Plants II. Dicotyledons. Almqvist \& Wiksell, Stockholm.

Hultén E, Fries M (1986) Atlas of North European Vascular Plants North of the Tropic of Cancer. Koeltz Scientific Books, Germany, Königstein.

Hurlbert AH, White EP (2005) Disparity between range mapand survey-based analyses of species richness: patterns, processes and implications. Ecology Letters, 8, 319-327.

Huston MA (2002) Introductory essay: critical issues for improving predictions. In: Predicting Species Occurrences: Issues of Accuracy and Scale (eds Scott JM, Heglund PJ, Morrison ML, Haufler JB, Raphael MG, Wall WA, Samson FB), pp. 7-21. Island Press, Covelo, CA.

IPCC (2007) Climate Change 2007: Impacts, Adaptation and Vulnerability: Summary for Policymakers. Working Group II Contribution to the Intergovernmental Panel on Climate Change Fourth Assessment Report.

Jalas J, Suominen J (1972-1991) Atlas Florae Europaeae. Societas Biologica Fennica Vanamo, Helsinki.

Jiménez-Valverde A, Lobo JM (2006) The ghost of unbalanced species distribution data in geographical model predictions. Diversity and Distributions, 12, 521-524.

Körner C (1999) Alpine Plant Life: Functional Plant Ecology of High Mountain Ecosystems. Springer-Verlag, Berlin. 
Liu CR, Berry PM, Dawson TP, Pearson RG (2005) Selecting thresholds of occurrence in the prediction of species distributions. Ecography, 28, 385-393.

Loehle C (1998) Height growth rate tradeoffs determine northern and southern range limits for trees. Journal of Biogeography, 25, 735-742.

Luoto M, Poyry J, Heikkinen RK, Saarinen K (2005) Uncertainty of bioclimate envelope models based on the geographical distribution of species. Global Ecology and Biogeography, 14, 575-584.

Lusby P, Wright JP (2001) Scottish Wild Plants, 2nd edn. Mercat Press, Edinburgh.

Macaulay Institute for Soil Research (1982) Soil Survey of Scotland, Sheet 47: Crieff. Craigiebuckler, Aberdeen, UK.

Macaulay Institute for Soil Research (1985) Soil Survey of Scotland, Sheet 51: Loch Tay. Craigiebuckler, Aberdeen, UK.

Mackey BG, Lindenmayer DB (2001) Towards a hierarchical framework for modelling the spatial distribution of animals. Journal of Biogeography, 28, 1147-1166.

MAFF (1988) Agricultural Land Classification of England and Wales. Ministry of Agriculture Fisheries and Food, London.

McEvoy D, Handley JF, Cavan G, Aylen J, Lindley S, Mcmorrow J, Glynn S (2006) Climate change and the visitor economy: the challenges and opportunities for England's northwest. Sustainability Northwest (Manchester) and UKCIP (Oxford), UK.

McPherson JM, Jetz W, Rogers DJ (2004) The effects of species' range sizes on the accuracy of distribution models: ecological phenomenon or statistical artefact? Journal of Applied Ecology, 41, 811-823.

McPherson JM, Jetz W, Rogers DJ (2006) Using coarse-grained occurrence data to predict species distributions at finer spatial resolutions - possibilities and limitations. Ecological Modelling, 192, 499-522.

Meusel H, Jäger E, Weinert E (1965) Vergleichende Chorologie der Zentraleuropäischen Flora. Gustav Fischer, Jena.

Meusel H, Jäger E, Weinert E (1992) Vergleichende Chorologie der Zentraleuropäischen Flora. Gustav Fischer, Jena.

Meusel H, Jäger E, Weinert E, Rauschert ST (1978) Vergleichende Chorologie der Zentraleuropäischen Flora. Gustav Fischer, Jena.

Morecroft MD, Paterson JP (2006) Effects of temperature and precipitation changes on plant communities. In: Plant Growth and Climate Change (eds Morison J, Morecroft MD), pp. 146164. Blackwell, Oxford.

Morecroft MD, Woodward FI (1996) Experiments on the causes of altitudinal differences in the leaf nutrient contents, size and delta C-13 of Alchemilla alpina. New Phytologist, 134, 471-479.

Nagy L (2003) The high mountain vegetation of Scotland. In: Alpine Biodiversity in Europe (eds Nagy L, Grabherr G, Körner C, Thompson DBA), pp. 39-46. Springer Verlag, Berlin.

Nogués-Bravo D, Araújo MB (2006) Species richness, area and climate correlates. Global Ecology and Biogeography, 15, 452-460.

Noss RF (2001) Beyond Kyoto: forest management in a time of rapid climate change. Conservation Biology, 15, 578-590.

O'Brien EM, Field R, Whittaker RJ (2000) Climatic gradients in woody plant (tree and shrub) diversity: water-energy dynamics, residual variation, and topography. Oikos, 89, 588-600.

Openshaw S (1984) The Modifiable Areal Unit Problem. Geo Abstracts, Norwich, UK.
Parmesan C, Yohe G (2003) A globally coherent fingerprint of climate change impacts across natural systems. Nature, 421, 37-42.

Pearce J, Ferrier S (2000) Evaluating the predictive performance of habitat models developed using logistic regression. Ecological Modelling, 133, 225-245.

Pearson R, Dawson TP, Berry PM, Harrison PA (2002) Species: a spatial evaluation of climate impact on the envelope of species. Ecological Modelling, 154, 289-300.

Pearson RG, Dawson TP (2003) Predicting the impacts of climate change on the distribution of species: are bioclimate envelope models useful? Global Ecology and Biogeography, 12, 361-371.

Pearson RG, Dawson TP (2004) Bioclimate envelope models: what they detect and what they hide. Global Ecology and Biogeography, 13, 471-473.

Pearson RG, Dawson TP, Liu C (2004) Modelling species distributions in Britain: a hierarchical integration of climate and land-cover data. Ecography, 27, 285-298.

Pearson RG, Thuiller W, Araújo MB et al. (2006) Model-based uncertainty in species range prediction. Journal of Biogeography, 33, 1704-1711.

Poore MD (1993) The alpine flora and Ben Lawers. In: Ben Lawers (ed. Mardon DK), pp. 10-25. National Trust for Scotland, Edinburgh.

Prentice IC, Cramer W, Harrison SP, Leemans R, Monserud RA, Solomon AM (1992) A global biome model based on plant physiology and dominance, soil properties and climate. Journal of Biogeography, 19, 117-134.

Qian H, Ricklefs RE (2000) Large-scale processes and the Asian bias in species diversity of temperate plants. Nature, 407, 180-182.

R Development Core Team (2005) R: A Language and Environment for Statistical Computing. R Foundation for Statistical Computing, Vienna, Austria.

Rahbek C, Graves GR (2001) Multiscale assessment of patterns of avian species richness. Proceedings of the National Academy of Sciences of the United States of America, 98, 4534-4539.

Randin CF, Dirnbock T, Dullinger S, Zimmermann NE, Zappa M, Guisan A (2006) Are niche-based species distribution models transferable in space? Journal of Biogeography, 33, 1689-1703.

Rodwell JS (2006) NVC Users Handbook. Joint Nature Conservation Committee, Peterborough.

Root TL, Price JT, Hall KR, Schneider SH, Rosenzweig C, Pounds JA (2003) Fingerprints of global warming on wild animals and plants. Nature, 421, 57-60.

Segurado P, Araújo MB (2004) An evaluation of methods for modelling species distributions. Journal of Biogeography, 31, 1555-1568.

Smith S, Gray D, Booth AB (2003) Ben Lawers SSSI NVC Survey 2003. Central Environmental Surveys, Dunblane, Perthshire, UK.

Stockwell DRB, Peterson AT (2002) Effects of sample size on accuracy of species distribution models. Ecological Modelling, 148, 1-13.

Svenning JC, Skov F (2004) Limited filling of the potential range in European tree species. Ecology Letters, 7, 565-573.

Swets JA (1988) Measuring the accuracy of diagnostic systems. Science, 240, 1285-1293. 
Thornton PE, Hasenauer H, White MA (2000) Simultaneous estimation of daily solar radiation and humidity from observed temperature and precipitation: an application over complex terrain in Austria. Agricultural and Forest Meteorology, 104, 255-271.

Thuiller W, Araujo MB, Lavorel S (2004a) Do we need land-cover data to model species distributions in Europe? Journal of Biogeography, 31, 353-361.

Thuiller W, Araújo MB, Lavorel S (2003a) Generalized models vs. classification tree analysis: predicting spatial distributions of plant species at different scales. Journal of Vegetation Science, 14, 669-680.

Thuiller W, Brotons L, Araujo MB, Lavorel S (2004b) Effects of restricting environmental range of data to project current and future species distributions. Ecography, 27, 165-172.

Thuiller W, Lavorel S, Araújo MB, Sykes MT, Prentice IC (2005) Climate change threats to plant diversity in Europe. Proceedings of the National Academy of Sciences of the United States of America, 102, 8245-8250.

Thuiller W, Vayreda J, Pino J, Sabate S, Lavorel S, Gracia C (2003b) Large-scale environmental correlates of forest tree distributions in Catalonia (NE Spain). Global Ecology and Biogeography, 12, 313-325.

Warren MS, Hill JK, Thomas JA et al. (2001) Rapid responses of British butterflies to opposing forces of climate and habitat change. Nature, 414, 65-69.

Welk E, Bruelheide H (2006) There may be bias in $R / P$ ratios (realized vs. potential range) calculated for European tree species - an illustrated comment on Svenning \& Skov (2004). Journal of Biogeography, 33, 2013-2018.

Wiens JA (1989) Spatial scaling in ecology. Functional Ecology, 3, 385-397.

Wiens JA (2002) Predicting species occurrences: progress, problems, and prospects. In: Predicting Species Occurrences: Issues of Accuracy and Scale (eds Scott JM, Heglund PJ, Morrison ML, Haufler JB, Raphael MG, Wall WA, Samson FB), pp. 739-749. Island Press, Covelo, CA.

Wintle BA, Elith J, Potts JM (2005) Fauna habitat modelling and mapping: a review and case study in the Lower Hunter Central Coast region of NSW. Austral Ecology, 30, 719-738.

Zimmermann NE, Kienast F (1999) Predictive mapping of alpine grasslands in Switzerland: species versus community approach. Journal of Vegetation Science, 10, 469-482.

\section{Appendix A}

Table A1 Results of bioclimate models for 20 species at macro and local scales. Prevalence refers to the occurrence of each species in $50 \mathrm{~km}$ grid cells or $2 \mathrm{~m} \times 2 \mathrm{~m}$ quadrats at macro and local scales, respectively

\begin{tabular}{|c|c|c|c|c|}
\hline \multirow[b]{2}{*}{ Species } & \multicolumn{2}{|c|}{ Macro model } & \multicolumn{2}{|l|}{ Local model } \\
\hline & $\begin{array}{l}\text { Prevalence } \\
(\%)\end{array}$ & AUC & $\begin{array}{l}\text { Prevalence } \\
(\%)\end{array}$ & AUC \\
\hline Alchemilla alpina $\mathrm{L}$. & 10 & 0.96 & 29 & 0.74 \\
\hline Calluna vulgaris (L.) Hull & 31 & 0.95 & 25 & 0.82 \\
\hline Carex bigelowii Torr. & 9 & 0.98 & 24 & 0.9 \\
\hline Deschampsia cespitosa (L.) & 40 & 0.98 & 17 & 0.66 \\
\hline \multicolumn{5}{|l|}{ P. Beauv. } \\
\hline Erica tetralix $\mathrm{L}$. & 13 & 0.99 & 13 & 0.96 \\
\hline Eriophorum vaginatum $\mathrm{L}$. & 31 & 0.97 & 11 & 0.73 \\
\hline Festuca vivipara (L.) Sm. & 6 & 0.99 & 46 & 0.88 \\
\hline Huperzia selago (L.) & 36 & 0.99 & 11 & 0.74 \\
\hline \multicolumn{5}{|l|}{ Bernh. } \\
\hline \multicolumn{5}{|l|}{ Ex Schrank \& Mart. } \\
\hline Juncus squarrosus L. & 16 & 0.97 & 30 & 0.79 \\
\hline Minuartia sedoides (L.) & 2 & 0.98 & 5 & 0.85 \\
\hline \multicolumn{5}{|l|}{ Hiern } \\
\hline Molinia caerulea (L.) & 38 & 0.98 & 14 & 0.75 \\
\hline \multicolumn{5}{|l|}{ Moench } \\
\hline Narthecium ossifragum (L.) & 12 & 0.99 & 19 & 0.86 \\
\hline \multicolumn{5}{|l|}{ Huds. } \\
\hline Persicaria vivipara (L.) & 21 & 0.98 & 12 & 0.66 \\
\hline Potentilla erecta (L.) & 44 & 0.99 & 46 & 0.9 \\
\hline \multicolumn{5}{|l|}{ Raeusch. } \\
\hline Salix herbacea L. & 9 & 0.97 & 8 & 0.86 \\
\hline $\begin{array}{l}\text { Selaginella selaginoides } \\
\text { (L.) P. Beauv. }\end{array}$ & 19 & 0.99 & 8 & 0.55 \\
\hline Silene acaulis (L.) Jacq. & 9 & 0.97 & 8 & 0.87 \\
\hline Thalictrum alpinum L. & 9 & 0.98 & 12 & 0.66 \\
\hline $\begin{array}{l}\text { Tricophorum cespitosum } \\
\text { (L.) Hartm. }\end{array}$ & 25 & 0.99 & 25 & 0.68 \\
\hline Viola palustris $\mathrm{L}$. & 33 & 0.99 & 10 & 0.66 \\
\hline
\end{tabular}

AUC $=$ Area under the curve of the receiver operating characteristic plot from generalized additive model predictions. Montane species are in bold. 